Springer Nature is making SARS-CoV-2 and COVID-19 research free. View research | View latest news | Sign up for updates

\title{
Preliminary Analysis of Slope Instability Processes Triggered in the Guilherme Creek Watershed (Nordeste Municipality, S. Miguel Island, Azores)
}

Advances in Natural Hazards and Hydrological Risks: Meeting the Challenge pp 55-58 | Cite as

- Paulo Maciel Amaral (1) Email author (amaral.paulomaciel@gmail.com)

- Rui Marques (2) (3)

- Isabel Duarte (4)

- António Pinho (4)

1. Environment and Society, Department of Geosciences, University of the Azores, , Ponta Delgada, Portugal

2. Centre for Information and Seismovolcanic Surveillance of the Azores, University of the Azores, , Ponta Delgada, Portugal

3. Research Institute for Volcanology and Risk Assessment, University of the Azores, , Ponta Delgada, Portugal

4. Centre GeoBiotec|UA and School of Science and Technology, Department of

Geosciences, University of Évora, , Évora, Portugal

Conference paper

First Online: 03 January 2020

- 40Downloads

Part of the Advances in Science, Technology \& Innovation book series (ASTI)

\begin{abstract}
The Nordeste Volcanic Complex is located in the NE sector of S. Miguel Island (Azores) and it is composed of geological formations with about 4 million years old, extremely weathered. This fact, allied to the steep slopes on the area, promotes the occurrence of slope instability phenomena. In particular, the Guilherme Creek watershed has a high recurrence of this type of geological hazard, mainly triggered by precipitation, which promotes a high density of landslides in the area. Considering as main objective the landslide susceptibility analysis in the Guilherme Creek watershed, using statistical/probabilistic methods, it is ongoing an inventory process of these phenomena in a GIS, based on the aerial photography interpretation and fieldwork. Currently, the inventory is concluded based on aerial photography from 1982 and
\end{abstract}


orthorectified aerial photography from 1995 to 2005. In order to validate and update the landslide inventory produced in the office, fieldwork has been carried out using, besides more traditional techniques, a drone (DJI Phatom 4 PRO). This tool has allowed studying steep slopes, which would otherwise be impossible to access in an area with a high forest density and very steep slopes. Until now, 517 landslides have been identified in the study area, mainly belonging to slides and falls typologies.

\section{Keywords}

Landslides Geomorphological evolution Geographic information systems

Nordeste volcanic complex São miguel island Azores

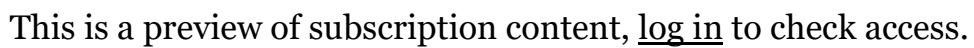

\section{References}

Duncan AM, Guest JE, Wallenstein N, Chester DK (2015) The older volcanic complexes of São Miguel, Azores: Nordeste and Povoação. In: Gaspar JL, Guest JE., Duncan AM, Barriga FJAS, Chester DK (eds) Volcanic geology of São Miguel island (Azores Archipelago). Geological Society, London, Memoirs, 44, pp 147-153

Google Scholar (https://scholar.google.com/scholar? q=Duncan\%20AM\%2C\%2oGuest\%20JE\%2C\%20Wallenstein\%20N\%2C\%20Chester\% 20DK\%20\%282015\%29\%20The\%20older\%20volcanic\%20complexes\%20of\%2oS\%C3 \%A30\%2oMiguel\%2C\%20Azores\%3A\%2oNordeste\%20and\%20Povoa\%C3\%A7\%C3\%A 30.\%20In\%3A\%2oGaspar\%2OJL\%2C\%2oGuest\%2OJE.\%2C\%2oDuncan\%2OAM\%2C\% 20Barriga\%20FJAS\%2C\%20Chester\%20DK\%20\%28eds\%29\%2oVolcanic\%2ogeology \%20of\%20S\%C3\%A30\%20Miguel\%2oisland\%20\%28Azores\%20Archipelago\%29.\%20 Geological\%2OSociety\%2C\%2OLondon\%2C\%20Memoirs\%2C\%2044\%2C\%2Opp\%2014 7\%E2\%80\%93153)

Fernandez AL (1980) Geology and petrology of the Nordeste volcanic complex, São Miguel, Azores. Geol Soc Am Bull, Part II 91:2457-2557

CrossRef (https://doi.org/10.1130/GSAB-P2-91-2457)

Google Scholar (http://scholar.google.com/scholar_lookup?

title=Geology\%20and\%2opetrology\%20of\%20the\%2oNordeste\%2ovolcanic\%2ocompl ex\%2C\%20S\%C3\%A30\%20Miguel\%2C\%20Azores\&author=AL.\%20Fernandez\&journa $\mathrm{l}=$ Geol\%20Soc\%20Am\%20Bull\%2C\%20Part\%20II\&volume=91\&pages=2457-

2557\&publication_year=1980)

Marques R (2013) In: de S. Miguel, Açores): Inventariação, (ed) caracterização e análise da susceptibilidade. Universidade dos Açores, Ponta Delgada (Tese de doutoramento).

Google Scholar (https://scholar.google.com/scholar?

q=Marques\%20R\%20\%282013\%29\%20In\%3A\%20de\%20S.\%20Miguel\%2C\%20A\%C3 \%A7ores\%29\%3A\%2oInventaria\%C3\%A7\%C3\%A30\%2C\%20\%28ed\%29\%2ocaracteriz a\%C3\%A7\%C3\%A30\%20e\%20an\%C3\%A1lise\%20da\%20susceptibilidade.\%2oUniversi dade\%2odos\%20A\%C3\%A7ores\%2C\%2oPonta\%2oDelgada\%20\%28Tese\%2ode\%2odo utoramento\%29.)

Silva RF, Marques R, Gaspar JL (2018) Implications of landslides typology and predisposing factor combinations for probabilistic landside susceptibility models: a case study in Lajedo Parish (Flores island, Azores-Portugal). Geosciences 8(5):153 CrossRef (https://doi.org/10.3390/geosciences8050153) 
Google Scholar (http://scholar.google.com/scholar_lookup?

title=Implications\%20of\%2olandslides\%20typology\%20and\%2opredisposing\%2ofacto r\%20combinations\%2ofor\%2oprobabilistic\%2olandside\%2osusceptibility\%2omodels \%3A\%20a\%2ocase\%2ostudy\%2oin\%2oLajedo\%2oParish\%20\%28Flores\%2oisland\%2 C\%20Azores\%E2\%80\%94Portugal\%29\&author=RF.\%20Silva\&author=R.\%20Marques \&author $=$ JL. $\% 20$ Gaspar\&journal $=$ Geosciences\&volume $=8 \&$ issue $=5 \&$ pages $=153 \&$ publi cation_year=2018)

\section{Copyright information}

(C) Springer Nature Switzerland AG 2020

\section{About this paper}

Cite this paper as:

Maciel Amaral P., Marques R., Duarte I., Pinho A. (2020) Preliminary Analysis of Slope Instability Processes Triggered in the Guilherme Creek Watershed (Nordeste Municipality, S. Miguel Island, Azores). In:

Fernandes F., Malheiro A., Chaminé H. (eds) Advances in Natural Hazards and Hydrological Risks: Meeting the Challenge. Advances in Science, Technology \& Innovation (IEREK Interdisciplinary Series for Sustainable Development). Springer, Cham

- First Online 03 January 2020

- DOI https://doi.org/10.1007/978-3-030-34397-2_11

- Publisher Name Springer, Cham

- Print ISBN 978-3-030-34396-5

- Online ISBN 978-3-030-34397-2

- eBook Packages Earth and Environmental Science

- Buy this book on publisher's site

- $\underline{\text { Reprints and Permissions }}$

\section{Personalised recommendations}

(C) 2019 Springer Nature Switzerland AG. Part of Springer Nature.

Not logged in Not affiliated 87.196.41.100 